\title{
PENGARUH INTELLECTUAL CAPITAL PADA NILAI PERUSAHAAN PERBANKAN
}

\author{
Novia Awaliyah, Retna Safriliana \\ Prodi Akuntansi Universitas Merdeka Malang \\ Jl. Terusan Dieng No. 62-64 Klojen, Sukun, Malang \\ Email: retnasafriliana@yahoo.com
}

\begin{abstract}
$A B S T R A C T$
The role of intellectual capital in knowledge-based business is increasingly required. Intellectual capital is belived to contribute to the improvement of frim value. The purpose of this study was to test empirically the effect of intellectual capital on firm value. Intellectual capital is calculated by value added intellectual coefficient (VAIC TM) and firm value measured by the Price To Book Value (PBV) and Earning Per Share (EPS). The population in this study are banking companies listed in Indonesia Stock Exchange during 2011-2015. The number of samples are 24 firm that are selected using pourposive sampling method. This study uses observational data for five periods, so the number of final samples are 120. The data were analyzed using simple linear regression. The analysis first regression showed that the constants of -0,222 and a significance value of 0.000 which is smaller than á (0.05). This suggests that the positive effect of intellectual capital on Price Book Value (PBV). And The analysis second regression showed that the constants of 0,993 and a significance value of 0.000 which is smaller than a (0.05). This suggests that the positive effect of intellectual capital on Earning Per Share (EPS).
\end{abstract}

Keywords: Intellectual Capital, Firm Value, value added intellectual coefficient (VAIC ${ }^{\text {TM) }}$ Price Book Value (PBV), Earning Per Share (EPS).

\section{PENDAHULUAN}

Aktivitas bisnis terus mengalami perkembangan sebagai salah satu dampak dari globalisasi ekonomi yang memicu terjadinya persaingan bebas bagi para pelaku ekonomidan bisnis.Perusahaan harus mengubah bisnis yang didasarkan pada tenaga kerja (Labor-Based Business) menuju pengetahuan bisnis (Knowledge Based Business) dengan karakteristik utama ilmu pengetahuan (Sawarjuwono dan Kadir 2003). Menurut Vazifehdoust et al. (2014) sistem new economic dikenal sebagai pengetahuan ekonomi yang tidak berwujud atau aset intelektual telah diakui sebagai sumber daya yang harus ada pada Perusahaan keuangan, farmasi, perbankan dan perhotelan yang tergantung pada intellectual capital(IC). Menurut Ulum (2008) Intellectual capital (IC) merupakan aset tidak berwujud secara oprasional sebagai material yang telah disusun dan dimanfaatkan untuk menghasilkan aset yang bernilai lebih tinggi. Pulic (2000) Memperkenalkan metode pengukuran IC secara tidak langsung dengan menggunakan Value Added Intellectual Coefficient (VAIC ${ }^{\mathrm{TM}}$ ) menggabungkan tiga komponen sumber daya perusahaan, yaitu Capital Employed / Physical Capital(VACA), Human Capital(VAHU), dan Structural Capital (STVA).

Nilai perusahaan meurut Ulum (2008) adalah nilai jual sebuah perusahaan yang masih atau sedang beroperasi, yang merupakan pandangan investor terhadap suatu perusahaan yang dilihat dari harga sahamnya.Industri jasa keuangan seperti Perbankan di Indonesia merupakan salah satu industri yang paling intensif menggunakan IC, sektor perbankan memiliki peran yang sangat penting untuk mendukung pergarakan perekonomian dalam Negara.Nilai perusahaan diukur dari beberapa aspek salah satunya adalah harga pasar saham perusahaan ada beberpa rasio yang dapat digunakan menghitung nilai perusahaan yaitu EPS

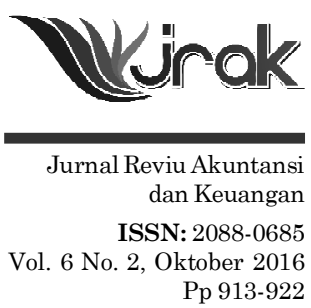


Pengaruh

Intellectual

Capital...

914

dan PBV. Penelitian mengenai IC ini telah dilakukan oleh beberapa peneliti. Berdasarkan latar belakang diatas maka, rumusan masalah akan dibahas dalam penelitian ini yaitu: (1) Apakah intellectual capital berpengaruh terhadap nilai perusahaan yang dukur dengan Price Book Value (PBV)? (2) Apakah intellectual capital berpengaruh terhadap nilai perusahaan yang dukur dengan Earning Per Share (EPS)?

\section{Pengaruh intellectual capital pada nilai perusahaan}

Chen et Q1. (2005) menyatakan bahwa investor cenderung akan membayar lebih tinggi atas saham perusahaan yang memiliki sumber daya intelektual yang lebih dibandingkan perusahaan dengan sumber daya intelektual yang rendah. Sedangkan menurut Ulum (2008) para Stakeholder memiliki wewenang untuk mempengaruhi manajer dalam proses pemanfaatan sumber daya perusahaan. Pemanfaatan sumber daya secara efektif dan efisien akan mendorong terciptanya nilai tambah pada perusahaan sehingga menarik perhatian parainvestor yang merupakan salah satu pihak yang berkepentingan pada perusahaan.

\section{Pengembangan Hipotesis \\ Pengaruh intellectual capital terhadap nilai perusahaan yang diukur dengan Price Book Value (PBV).}

Salah satu peran intellectual capital adalah membantu perusahaan dalam proses menciptakan nilai. Perusahaan yang memiliki intellectual capital tinggi akan di respon positif oleh investor dengan melakukan penambahan modal. Nilai perusahaan yang di ukur dengan menggunakan PBV akan menunjukan perbandingan antara harga saham dengan nilai buku sahamnya. Bahwa intellectual Capital tidak berpengaruh pada nilai perusahaan.Berdasarkan uraian diatas dapat diusulkan hipotesis sebagai berikut:

$\mathrm{H}_{1}$ : Intellectual capital berpengaruh terhadap nilai perusahaan yang diukur dengan Price Book Value (PBV). Pengaruh intellectual capital terhadap nilai perusahaan yang diukur
dengan Earning per Share (EPS).

Penciptaan nilai dapat dilakukan salah satunya dengan pengelolaan intellectual capital, kepemilikan serta pemanfaatan sumberdaya intellectual capital memungkinkan perusahaan mencapai keunggulan bersaing dan meningkatkan nilai tambah. Keunggulan bersaing yang dimiliki perusahaan akan menarik perhatian investor untuk berinvestasi sehingga nilai perusahaan tersebut meningkat dengan return yang diperoleh. Return yang diperoleh perusahaan akan menentukan besarnya jumlah EPS. Melalui EPS para pemegang saham akan mengetahui besarnya laba bersih perusahaan yang mereka terima. Penelitian Vazifehdoust et al. (2014) menyatakan bahwa modal intelektual tidak berpengaruh terhadap EPS. Berdasarkan uraian diatas hipotesis dalam penelitian ini adalah sebagai berikut:

$\mathrm{H}_{2}$ : Intellectual capital berpengaruh terhadap nilai perusahaan yang diukur dengan Earning per Share (EPS)

\section{METODE}

\section{Populasi dan teknik penarikan sampel}

Perusahaan yang dianalisis dalam penelitian ini adalah perusahaan perbankan yang terdaftar di Bursa Efek Indonesia (BEI) selama tahun 2011-2015. Teknik pengambilan sampel dilakukan dengan Purposive Sampling yaitu metode penarikan sampel dengan kriteria tertentu. Kriteria sampel yang digunakan dalam penelitian ini yaitu: 
1. Perusahaan perbankan yang terdaftar diBursa Efek Indonesia periode 20112015.

2. Perusahaan perbankan yang menerbitkan laporan keuangan/ annual report secara berturut- turut periode 2011-2015.

3. Perusahaan perbankan yang tidak menunjukkan laba dan ekuitas negatif selama periode 2011-2015.

4. Perusahaan perbankan yang menggunakan mata uang rupiah.

5. Perusahaan yang menerbitkan kapitalisasi pasar diBursa Efek Indonesia periode 2011-2015.

\section{Variabel Penelitian}

\section{Intellectual capital.}

Intellectual capital merupakan variabel independenyang dihitung dengan jumlah dari tiga elemen khusus utama oragnisasi (Human Capital, Struktural Capital dan Costumer Capital) IC diukur dengan VAIC ${ }^{\text {TM }}$ yang di kembangkan oleh Pulic (2000):

a) Menghitung value added (VA)

$\mathrm{VA}=\mathrm{OUT}-\mathrm{IN}$

Keterangan:

VA = Value Added

Output (OUT) = Total penjualan dan pendapatan lain

Input (IN) = Beban dan biaya-biaya (selain beban karyawan).

b) Menghitung Value Added Capital Employed (VACA)

$$
\mathrm{VACA}=\frac{\mathrm{VA}}{\mathrm{CE}}
$$

Keterangan:

$\mathrm{VA}=$ Value Added, yaitu total penjualan dan pendapatan lain dikurangi dengan beban dan biaya-biaya (selain beban karyawan).

$\mathrm{CE}=$ Capital Employed, yaitu dana yang tersedia atau dimiliki oleh perusahaan (total ekuitas).

c) Menghitung Value Added Human Capital (VAHU)

$\mathrm{VAHU}=\frac{\mathrm{VA}}{\mathrm{HC}}$

Keterangan:

VA = Value Added, yaitu total penjualan dan pendapatan lain dikurangi dengan beban dan biaya-biaya (selain beban karyawan).

$\mathrm{HC}=$ Human Capital, yaitu beban karyawan atau tenaga kerja yang ditanggung oleh perusahaan (total gaji, upah dan pendapatan karyawan).

d) Menghitung Structural Capital Value Added (STVA)

STVA $=\frac{\mathrm{SC}}{\mathrm{VA}}$

Keterangan:

$\mathrm{SC}$ (structural capital) $=\mathrm{VA}-\mathrm{HC}$

$\mathrm{VA}$

= Value Added 


\section{Pengaruh Intellectual Capital...}

e) Menghitung ValueAdded Intellectual Coefficients(VAIC ${ }^{\mathrm{TM}}$ )

$\mathrm{VAIC}^{\mathrm{TM}}=\mathrm{VACA}+\mathrm{VAHU}+\mathrm{STVA}$

\section{Nilai perusahaan}

Nilai perusahaan sebagai variabel dependen adalah harga yang dibayar oleh calon pembeli apabila perusahaan tersebut dijual.

1. Price Book Value(PBV). Rasio ini menggambarkan seberapa besar pasar menghargai nilai buku saham suatu perusahaan. Dihitung menggunakan rumus (Tandelilin, 2010):

$$
\text { PBV }=\frac{\text { harga saham penutupan }}{\text { nilai buku perlembar saham }}
$$

2. Earning Per Share (EPS). Rasio ini menunjukkan besarnya laba bersih perusahaan yang dibagikan kepada pemegang saham. Rumus untuk menghitung EPS (Tandelilin, 2010):

$$
\text { EPS }=\frac{\text { laba bersih setelah bunga dan pajak }}{\text { jumlah saham beredar }} .
$$

\section{Teknik Analisis Data}

Teknik analisis data yang digunakan dalam penelitian ini adalah regresi linier sederhana.Analisis regresi linier digunakan untuk mengukur besarnya pengaruh variabel independen terhadap variabel dependen.Penelitian ini menggunakan regresi linier sederhana karena hanya terdapat satu variabel independen. Langkah-langkahnya:

1. Statistic deskriptif. Memberikan gambaran atau deskripsi mengenai suatu data yang dilihat dari rata-rata (mean), standar deviasi, nilai maksimum dan nilai minimum (Yamin dan Kurniawan, 2014). Statistik deskriptif dalam penelitian ini akan mendeskripsikan nilai dari variabel VAIC ${ }^{\text {TM }}$, PBV dan EPS.

2. Melakukan Uji Normalitas, bertujuan untuk menguji apakah pada model regresi, variabel pengganggu atau residual mempunyai distribusi normal atau mendekati normal. Pengujian normalitas data dilakukan dengan uji monte carlo. Residual berdistribusi normal apabila tingkat signifikannya menunjukkan nilai yang lebih besar dari 0,05.

3. Menentukan model regresi linier. Penelitian ini menggunakan satu model regresi linier sederhana (Yamin dan Kurniawan, 2014). Model regresi dalam penelitian ini adalah sebagai berikut:

$$
\begin{aligned}
& Y 1=a+b_{1} x+e \\
& Y 2=a+b_{1} x+e
\end{aligned}
$$

Keterangan:

$\mathrm{Y} 1$ = price book value (PBV)

Y2 = Earning Per Share (EPS)

$\mathrm{X}=$ value added intellectual coefficients $\left(\mathrm{VAIC}^{\mathrm{TM}}\right.$ )

a $=$ kostanta

$b_{1} \quad=$ koefisien regresi

e $=$ eror

4. Menguji hipotesis

a. Koefisien Determinasi $\left(\mathrm{R}^{2}\right)$

Menguji koefisien determinasi () digunakan untuk mengukur seberapa jauh kemampuan model dalam menerangkan variasi variable dependen. 
Nilai koefisien determinasi () adalah nol dan satu. Melalui uji ini akan diketahui seberapa besar variabel dependen mampu dijelaskan oleh variabel independen, sedangkan sisanya dijelaskan oleh sebab-sebab lain yang tidak diteliti.

b. Menguji Hipotesis parsial (uji t)

Uji hipotesis parsial digunakan untuk mengetahui masing-masing variabel independen terhadap variabel dependen.Uji parsial dilakukan untuk menguji hipotesis pertama dan kedua. Pengambilan keputusan dalam pengujian hipotesis adalah:

1) Tingkat signifikasi ( $\operatorname{sig} t) \leq 0,05$ maka hipotesis alternatif diterima signifikan.

2) Tingkat signifikasi (sig t) > 0,05 maka hipotesis alternatif ditolak (tidak signifikan).

\section{HASIL DAN PEMBAHASAN}

\section{Pengujian Normalitas}

Pengujian normalitas dalam penelitian ini dilakukan dengan menggunakan uji statistik monte carlo.Tabel dibawah ini menyajikan hasil pengujian normalitas.

\begin{tabular}{|ll|r|r|r|}
\hline & & LOG_VAIC & LOG_PBV & LOG_EPS \\
\hline Normal & Mean & 120 & 120 & 120 \\
Parameters & a.b & 0,5296 & 0,1027 & 1,8987 \\
Most Extreme & Sdt.Deviation & 0,14334 & 0,26757 & 0,63760 \\
Differences & Absolute & 0,064 & 0,057 & 0,101 \\
& Positive & 0,064 & 0,057 & 0,101 \\
Test Statistic & Negative & $-0,039$ & $-0,038$ & $-0,097$ \\
Monte Carlo Sig. & Sig. & 0,064 & 0,057 & 0,101 \\
(2-tailed) & & $0,675^{e}$ & $0,815^{e}$ & 0,164 \\
\hline
\end{tabular}

Sumber ' Dafa sekınder vand diolah (2017)

Transformasi data dilakukan dalam penelitian ini karena data tidak terdistribusi secara normal.Tabel 3 diatas menyajikan nilai signifikasi Monte Carlo variabel VAIC ${ }^{\mathrm{TM}}$, PBV dan EPS setelah dilakukan transformasi data.Nilai signifikasi ketiga variabel tersebut secara berurutan adalah sebesar 0,675; 0,815 dan 0,164. Nilai signifikasi tersebut lebih besar dari 0,05 yang berarti data dalam penelitian ini berdistribusi normal.

\section{Model Regresi Linier}

Analisis regresi linier digunakan untuk mengetahui pengaruh antara variabel independen dengan variabel dependen.Penelitian ini menggunakan dua model regresi linier sederhana. Berdasarkan hasil pengolahan data dengan SPSS, dapat disimpulkan model regresi dalam penelitian ini sebagai berikut:

$\mathrm{PBV}=-0,222+0,613$ VAIC $^{\text {TM }}$

Persamaan pertama dapat diartikan sebagai berikut:

a. Konstanta sebesar -0,222 menunjukkan apabila VAIC ${ }^{\text {TM }}$ bernilai nol, maka PBV bernilai sebesar $-0,222$.

b. Koefisien regresi untuk VAIC ${ }^{\mathrm{TM}}$ adalah sebesar 0,613 mempunyai arti apabila terjadi kenaikan VAIC ${ }^{\text {TM }}$ sebesar satu satuan, maka akan terjadi peningkatan PBV sebesar 0,613 .

$\mathrm{EPS}=0,993+1,711 \mathrm{VAIC}^{\mathrm{TM}}$ 


\section{Pengaruh Intellectual Capital...}

Tabel 2

Hasil Uji Koefisien Determinasi Model Regresi 1

Tabel 3

Hasil Uji Koefisien Determinasi Model Regresi 2

Tabel 4 Uji Hipotesis 1

Tabel 5 Uji Hipotesis 2

Persamaan kedua dapat diartikan sebagai berikut:

a. Konstanta sebesar 0, 993 menunjukkan apabila VAIC ${ }^{\mathrm{TM}}$ bernilai nol, maka EPS bernilai sebesar 0, 993.

b. Koefisien regresi untuk VAICTM adalah sebesar 1,711 mempunyai arti apabila terjadi kenaikan VAIC ${ }^{\text {TM }}$ sebesar satu satuan, maka akan terjadi peningkatan EPS sebesar 1,711 .

\section{Pengujian Hipotesis}

a. Pengujian koefisien Determinasi $\left(\mathrm{R}^{2}\right)$

Koefisien Determinasi $\left(\mathrm{R}^{2}\right)$ digunakan untuk mengukur seberapa jauh kemampuan model dalam menerangkan variasi variabel dependen. Melalui hasil ini akan diketahui seberapa besar variabel dependen mampu dijelaskan oleh variabel independen.

\begin{tabular}{ccccc}
\hline Model & $\mathbf{R}$ & $\begin{array}{c}\mathbf{R} \\
\text { Square }\end{array}$ & $\begin{array}{c}\text { Adjusted } \mathbf{R} \\
\text { Square }\end{array}$ & $\begin{array}{c}\text { Std. Error of the } \\
\text { Estimate }\end{array}$ \\
\hline 1 & $0,328^{\mathrm{a}}$ & 0,108 & 0,100 & 0,25380 \\
\hline
\end{tabular}

Sumber: Data sekunder yang diolah (2017)

Berdasarkan tabel diatas, nilai adjusted $R$ square $\left(\mathrm{R}^{2}\right)$ diketahui sebesar 0,100. Nilai ini menunjukkan bahwa pengaruh variabel independen yaitu value added intellectual coefficients (VAIC ${ }^{\mathrm{TM}}$ ) sebagai intellectual capitaldalam menjelaskan variabel dependen yaitu Price Book Value (PBV) sebagai Nilai Perusahaan pada model regresi pertama sebesar $10 \%$ sedangkan sebesar $90 \%$ dipengaruhi oleh faktor lain yang tidak diteliti.

\begin{tabular}{ccccc}
\hline Model & $\mathbf{R}$ & $\begin{array}{c}\mathbf{R} \\
\text { Square }\end{array}$ & $\begin{array}{c}\text { Adjusted } \mathbf{R} \\
\text { Square }\end{array}$ & $\begin{array}{c}\text { Std. Error of the } \\
\text { Estimate }\end{array}$ \\
\hline 2 & $0,385^{\mathrm{a}}$ & 0,148 & 0,141 & 0,59106 \\
\hline
\end{tabular}

Sumber: Data Sekunder yang diolah (2017)

Berdasarkan tabel diatas, nilai adjusted $R$ square $\left(\mathrm{R}^{2}\right)$ diketahui sebesar 0,141. Nilai ini menunjukkan bahwa pengaruh variabel independen yaitu value added intellectual coefficients (VAIC ${ }^{\mathrm{TM}}$ ) sebagai intellectual capitaldalam menjelaskan variabel dependen yaitu Earning Per Share (EPS) sebagai Nilai Perusahaan pada model regresi kedua sebesar $14,1 \%$ sedangkan sebesar $85,9 \%$ dipengaruhi oleh faktor lain yang tidak diteliti.

\begin{tabular}{|c|c|c|c|c|c|}
\hline \multirow[t]{2}{*}{ Variabel } & \multicolumn{2}{|c|}{$\begin{array}{c}\text { Unstandardized } \\
\text { Coefficients }\end{array}$} & \multirow{2}{*}{$\begin{array}{c}\begin{array}{c}\text { Standardized } \\
\text { Coefficients }\end{array} \\
\text { Beta }\end{array}$} & \multirow[t]{2}{*}{$\mathrm{T}$} & \multirow[t]{2}{*}{ Sig. } \\
\hline & B & Std. Error & & & \\
\hline Konstanta & $-0,222$ & 0,089 & & $-2,493$ & 0,014 \\
\hline LOG_VAIC & 0,613 & 0,162 & 0,328 & 3,776 & 0,000 \\
\hline
\end{tabular}

Dependent Variable: LOG_PBV

Sumber: Data Sekunder yang diolah (2017)

Secara Statistik tingkat signifikasi $(\alpha)$ yang sering digunakan adalah $5 \%(0,05)$, jika signifikasi (sig t $\leq 0,05$ maka hipotesis alternatif diterima. Hasil analisis bahwa nilai signifikasi value added intellectual coefficients (VAIC ${ }^{\text {TM) }}$ sebesar 0,000. Maka $\mathrm{H} 1$ diterima pada tingkat $\alpha=0,05$ dan bernilai positif. Hal ini berarti secara parsial variable value added intellectual coefficients (VAIC ${ }^{\mathrm{TM}}$ ) berpengaruh signifikan terhadap price book value (PBV).

\begin{tabular}{|c|c|c|c|c|c|}
\hline \multirow{2}{*}{ Variabel } & \multicolumn{2}{|c|}{$\begin{array}{l}\text { Unstandardized } \\
\text { Coefficients }\end{array}$} & \multirow{2}{*}{$\begin{array}{c}\begin{array}{c}\text { Standardized } \\
\text { Coefficients }\end{array} \\
\text { Beta }\end{array}$} & \multirow[t]{2}{*}{$\mathrm{T}$} & \multirow[t]{2}{*}{ Sig. } \\
\hline & B & Std. Error & & & \\
\hline Konstanta & 0,993 & 0,207 & & 4,788 & 0,000 \\
\hline LOG_VAIC & 1,711 & 0,378 & 0,385 & 4,525 & 0,000 \\
\hline
\end{tabular}

Dependent Variable: LOG_EPS

Sumber: data sekunder yang diolah (2017) 
Secara Statistik tingkat signifikasi $(\alpha)$ yang sering digunakan adalah $5 \%$ $(0,05)$ dengan level of significance $95 \%$. Tingkat signifikasi (sig t $) \leq 0,05$ maka hipotesis alternatif diterima signifikan. Hasil analisis bahwa nilai signifikasi value added intellectual coefficients $\left(\mathrm{VAIC}^{\mathrm{TM}}\right.$ ) sebesar 0,000 . Maka $\mathrm{H} 2$ diterima pada tingkat $\alpha=0,05$ dan bernilai positif. Hal ini berarti secara parsial variable value added intellectual coefficients (VAIC ${ }^{\mathrm{TM}}$ ) berpengaruh signifikan terhadap earning per share (EPS).

\section{PEMBAHASAN HASIL PENELITIAN}

\section{Pengaruh Intellectual Capital terhadap nilai perusahaan yang diukur dengan Price Book Value (PBV).}

Berdasarkan hasil pengujian hipotesis pertama menunjukkan bahwa intellectual capital berpengaruh terhadap nilai perusahaan yang diukur dengan price book value (PBV). Hasil ini juga sesuai dengan teori stakeholder yang menyatakan bahwa pengelolaan seluruh intellectual capital yang diukur dengan menggunakan

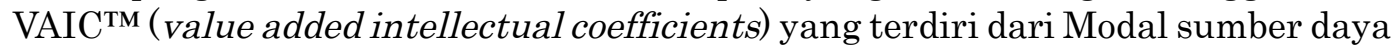
manusia (human capital), Modal Struktural (Structural Capital atau Organizational Capital) dan Modal Relasional (Relational Capital atau Costumer Capital) secara efektif terbukti meningkatkan nilai perusahaan yang diukur dengan menggunakan PBV.

Perusahaan Perbankan merupakan sektor jasa yang intensif membutuhkan intellectual capital khususnya modal sumber daya manusia (human capital) karena modal yang ada pada sektor perbankan berfokus pada asset tidak berwujud. Ketika modal sumber daya manusia yang terdiri dari pengetahuan, kompetensi, keterampilan dan pengalaman digunakan secara efisien maka akan mengurangi kesalahan-kesalahan yang dilakukan oleh manusia (human eror), sehingga dapat memberikan manfaat bagi perusahaan yang digunakan untuk menambah value added.

IC yang dikelola secara efisien oleh perusahaan akan meningkatkan apresiasi pasar terhadap nilai perusahaan. Nilai perusahaan tercermin dari harga saham yang dapat diukur menggunakan PBV, dengan mengetahui PBV investor dapat memberikan gambaran langsung mengenai suatu perusahaan oleh karena itu, ketika IC dikelola dengan maksimal dapat menjadikan perusahaan pada performa yang baik, dan dengan adanya performa yang baik yang ditunjukkan oleh perusahaan maka akan menarik banyak investor untuk berinvestasi pada perusahaan tersebut, sehingga nilai suatu perusahaan tersebut mengalami peningkatan.Jikasuatu perusahaan memiliki harga saham yang fluktuatif atau relatif stabil maka investor akan menempatkan nilai yang tinggi atas saham tersebut.

\section{Pengaruh Intellectual Capital terhadap Nilai Perusahaan yang diukur dengan Earning per Sahre (EPS).}

Berdasarkan hasil pengujian hipotesis kedua menunjukkan bahwa intellectual capital berpengaruh terhadap nilai perusahaan yang diukur dengan earning per share (EPS).Pengelolaanseluruh intellectual capital yang diukur dengan menggunakan VAIC ${ }^{\mathrm{TM}}$ (value added intellectual coefficients) yang terdiri dari Modal sumber daya manusia (human capital), Modal Struktural (Structural Capital atau Organizational Capital) dan Modal Relasional (Relational Capital atau Costumer Capital) secara efektif terbukti mampu meningkatkan nilai perusahaan yang diukur dengan menggunakan EPS.

Pengelolaan IC yang baik oleh perusahaan secara efektif dan efisien akan mencerminkan kinerja perusahaan yang baik, dengan demikian maka perusahaan akan memperoleh laba yang tinggi dan tentu saja akan berdampak pada besarnya laba yang dihasilkan untuk setiap lembar sahamnya, sehingga modal sumber daya 
Pengaruh

Intellectual

Capital... manusia yang terdiri dari pengetahuan, kompetensi, keterampilan dan pengalaman digunakan secara efisien akan menghasilkan kinerja yang optimal dan laba yang meningkat,berarti laba persaham perusahaan akan turut meningkat.

EPS yang tinggi disuatu perusahaan dinilai publik mempunyai kinerja dan nilai yang baik, semakin besar laba yang dihasilkan untuk setiap lembar saham oleh suatu perusahaan mencerminkan bahwa deviden yang akan diterima oleh pemegang saham akan semakin besar pula. Hal ini tentunya akan menarik para investor untuk menanamkan modalnya ke perusahaan yang memiliki IC yang dimanfaatkan secara efektif dan efisien.

Hasil penelitian ini berbeda dengan yang dilakukan oleh Vazifehdoust et al. (2014) menyatakan bahwa modal intelektual tidak berpengaruh terhadap EPS.19 perusahaan manufaktur di Bursa Efek Tehran iran dinilai masih kurang baik dan belum mampu mencerminkan IC yang baik yang terlihat dari kinerja perusahaannya yang diukur dengan EPS.

\section{SIMPULAN}

Berdasarkan Hasil penelitian mengenai "Pengaruh intellectual capital pada nilai perusahaan perbankan" Peneliti berhasil menyimpulkan bahwa:

1. Penelitian ini berhasil membuktikan bahwa Intellectual capital berpengaruh terhadap nilai perusahaan yang diukur dengan price book value (PBV). Dengan demikian Hasil ini sesuai dengan teori stakeholder yang menyatakan bahwa pengelolaan seluruh sumber daya perusahaan berupa Modal sumber daya manusia (human capital), Modal Struktural (Structural Capital atau Organizational Capital) dan Modal Relasional (Relational Capital atau Costumer Capital) secara efektif meningkatkan nilai perusahaan yang diukur dengan menggunakan PBV. IC yang dikelola secara efisien oleh perusahaan akan meningkatkan nilai perusahaan. Dengan mengetahui PBV investor dapat memberikan gambaran langsung mengenai suatu perusahaan oleh karena itu, ketika IC dikelola dengan maksimal dapat menjadikan perusahaan pada performa yang baik, dan dengan adanya performa yang baik yang ditunjukkan oleh perusahaan maka akan menarik banyak investor untuk berinvestasi pada perusahaan tersebut, sehingga nilai suatu perusahaan tinggi.

2. Penelitian ini berhasil mendapatkan bukti empiris bahwa Intellectual capital berpengaruh terhadap nilai perusahaan yang diukur dengan earning per share (EPS).Modal sumber daya manusia (human capital), Modal Struktural (Structural Capital atau Organizational Capital) dan Modal Relasional (Relational Capital atau Costumer Capital) secara efektif meningkatkan nilai perusahaan. Pengelolaan IC yang baik oleh perusahaan secara efektif mencerminkan kinerja perusahaan yang baik, dengan demikian maka perusahaan akan memperoleh laba yang tinggi, ketika modal sumber daya manusia digunakan secara efisien akan menghasilkan kinerja yang optimal dan laba yang meningkat,berarti laba persaham perusahaan akan turut meningkat. EPS yang tinggi disuatu perusahaan dinilai publik mempunyai kinerja dan nilai yang baik, semakin besar laba yang dihasilkan untuk setiap lembar saham oleh suatu perusahaan mencerminkan bahwa deviden yang akan diterima oleh pemegang saham akan semakin besar pula. Hal ini tentunya akan menarik para investor untuk menanamkan modalnya ke perusahaan yang memiliki IC yang dimanfaatkan secara efektif dan efisien.

\section{Saran}

Berdasarkan keterbatasan dalam penelitian ini, maka disarankan bagi penelitian selanjutnya agar: 
1. Penelitian selanjutnya diharapkan dapat mencakup perusahaan dari semua jenis industri sehingga hasil penelitian lebih dapatdi generalisasi.

2. Penelitian selanjutnya diharapkan dapat memperpanjang periode pengamatan sehingga pengaruh intellectual capitalpada nilai perusahaan lebih konsisten.

3. Penelitian selanjutnya menambahkan variabel lain selain IC yang berpengaruh terhadap variabel nilai perusahaan

\section{Keterbatasan penelitian}

Penelitian ini memiliki keterbatasan yang apabila diatasi pada penelitian selanjutnya akan dapat memperbaiki hasil penelitian.

1. Pemilihan sampel dalam penelitian ini dilakukan dengan metode purposive sampling sehingga sampel yang diperoleh menjadi lebih sedikit.

2. Sampel perusahaan yang digunakan dalam penelitian ini hanya menggunakan satu jenis perusahaan, hanya terbatas pada perusahaan jasa perbankan yang terdaftar di Bursa Efek Indonesia.

3. Penggunaaan akun-akun yang menimbulkan banyak interpretasi, karena karekteristik perusahaan perbankan yang berbeda dengan perusahaan jenis lainnya.

\section{DAFTAR PUSTAKA}

Chen, M. C., S. J. Cheng dan Y. Hwang. 2005. "An Empirical Investigation of the Relationship Between Intellectual Capital and Firm's Market Value and Financial Performance". Journal of Intellectual Capital.Vol. 6 No. 2. pp. 159176.

Pulic, A. 2000.”VAIC - An Accounting Tool for IC Management”. International Journal of Technology Management. Vol. 20 No. 5.

Sawarjuwono, T. dan A. P. Kadir. 2003. "Intellectual Capital: Perlakuan, Pengukuran dan Pelaporan (Sebuah Library Research)". Jurnal Akuntansi dan Keuangan. Vol. 5 No. 1. pp. 35-57.

Tandelilin, E. 2010. Portofolio dan Investasi: Teori dan Aplikasi. Edisi Pertama. Kanisius. Yogyakarta.

Ulum, I. 2008. "Intellectual Capital Performance Sektor Perbankan di Indonesia". Jurnal Akuntansi dan Keuangan.Vol. 10. pp.77-84.

Vazifehdoust, H., M. R. Khajenasir dan H. Karami. 2014. "A study on the effect of intellectual capital on firm performance: Evidence from Tehran Stock Exchange". Management Science Letters.Vol. 4. pp.559-566.

Yamin, S. dan H. Kurniawan. 2014. SPSS Complete Teknik Analisis Statistic Terlengkap Dengan Software Spss. Salemba Infotek. Jakarta. 
